\title{
Bioaccumulation of Toxic Metals in Commercially Valuable Fish from the Western Region of Ghana
}

\author{
Fosu-Mensah BY ${ }^{1, *}$, Ofori $A^{1}$, Ofosuhene $M^{2}$, Ofori-Attah $E^{2}$, Nunoo KKE $^{3}$, Tuffour $I^{2}$, Gordon $C^{1}$, \\ Arhinful $D^{4}$, Nyarko AK ${ }^{2,5}$, Appiah-Opong $\mathrm{R}^{2}$ \\ ${ }^{1}$ Institute of Environment and Sanitation Studies, University of Ghana, Ghana \\ ORCID ID: 0000-0003-3569-472X \\ ${ }^{2}$ Department of Clinical Pathology, Noguchi Memorial Institute for Medical Research (NMIMR), College of Health Sciences, \\ University of Ghana, Ghana \\ ${ }^{3}$ Department of Marine and Fisheries Sciences, University of Ghana, Ghana \\ ${ }^{4}$ Department of Epidemiology, Noguchi Memorial Institute for Medical Research, College of Health Sciences, University of Ghana, \\ Ghana \\ ${ }^{5}$ University of Ghana School of Pharmacy, College of Health Sciences, University of Ghana, P.O. Box KB 52, Legon, Ghana
}

Received June 29, 2021; Revised September 7, 2021; Accepted October 17, 2021

\section{Cite This Paper in the following Citation Styles}

(a): [1] Fosu-Mensah BY, Ofori A, Ofosuhene M, Ofori-Attah E, Nunoo FKE3, Tuffour I, Gordon C, Arhinful D, Nyarko AK, Appiah-Opong R, "Bioaccumulation of Toxic Metals in Commercially Valuable Fish from the Western Region of Ghana," Universal Journal of Public Health, Vol. 9, No. 5, pp. 296 - 305, 2021. DOI: 10.13189/ujph.2021.090512.

(b): Fosu-Mensah BY, Ofori A, Ofosuhene M, Ofori-Attah E, Nunoo FKE3, Tuffour I, Gordon C, Arhinful D, Nyarko AK, Appiah-Opong R (2021). Bioaccumulation of Toxic Metals in Commercially Valuable Fish from the Western Region of Ghana. Universal Journal of Public Health, 9(5), 296 - 305. DOI: 10.13189/ujph.2021.090512.

Copyright $\mathrm{C} 2021$ by authors, all rights reserved. Authors agree that this article remains permanently open access under the terms of the Creative Commons Attribution License 4.0 International License

\begin{abstract}
Fish is an important source of protein, however as human impacts on the environment through industrialization, mining and farming among others is resulting in increased concentration of toxic metals in them. The levels of copper $(\mathrm{Cu})$, arsenic $(\mathrm{As})$, zinc $(\mathrm{Zn})$, lead $(\mathrm{Pb})$, cadmium $(\mathrm{Cd})$, mercury $(\mathrm{Hg})$, and selenium $(\mathrm{Se})$ were analysed in fish samples from the southwestern coast of Ghana using acid digestion and atomic absorption spectrophotometer method. A total of 71 fish species were sampled where 35 species were collected in the wet season (October, 2014) whereas 36 species were collected in the dry season (March, 2015). The average levels of heavy metals detected in the wet season were $1.08 \mathrm{mg} / \mathrm{kg}$ for $\mathrm{Cu}$, $9.79 \mathrm{mg} / \mathrm{kg}$ for $\mathrm{Zn}, 4.80 \mathrm{mg} / \mathrm{kg}$ for Se, $0.06 \mathrm{mg} / \mathrm{kg}$ for $\mathrm{Pb}$, $0.03 \mathrm{mg} / \mathrm{kg}$ for Hg, $0.02 \mathrm{mg} / \mathrm{kg}$ for As, and $0.01 \mathrm{mg} / \mathrm{kg}$ for $\mathrm{Cd}$. The average values of heavy metals in fish samples analysed in the dry season were $2.17 \mathrm{mg} / \mathrm{kg}$ for $\mathrm{Cu}, 4.55$ $\mathrm{mg} / \mathrm{kg}$ for $\mathrm{Zn}, 8.13 \mathrm{mg} / \mathrm{kg}$ for $\mathrm{Se}, 0.06 \mathrm{mg} / \mathrm{kg}$ for $\mathrm{Pb}, 0.03$ $\mathrm{mg} / \mathrm{kg}$ for $\mathrm{Hg}, 0.09 \mathrm{mg} / \mathrm{kg}$ for As, and $0.005 \mathrm{mg} / \mathrm{kg}$ for Cd. The results showed that the average levels of toxic metals analysed in the wet season increased in the order of $\mathrm{Cd}<\mathrm{As}<\mathrm{Hg}<\mathrm{Pb}<\mathrm{Cu}<\mathrm{Zn}<\mathrm{Se}$ whereas the dry season increased in the order of $\mathrm{Cd}<\mathrm{Hg}<\mathrm{Pb}<\mathrm{As}<\mathrm{Cu}<\mathrm{Zn}<\mathrm{Se}$. The
\end{abstract}

levels of all seven heavy metals were below the FAO/WHO Maximum Permissible Limits (MPL), Australia New Zealand Food Standards, EU, Australian National Health and Medical Research Council (ANHMRC) standards. Hence the consumption of these fish poses no public health concern. The estimated daily intake of the various toxic metals analysed were lower than the daily intake of their respective toxic metals. The non-carcinogenic health risk to adults and children showed that the Total Targeted Hazard Quotients (TTHQ) was less than $1(<1)$ hence poses no health risk to humans.

Keywords Commercial Fish, Health Risk, Arsenic, Cadmium, Copper, Mercury, Lead, Selenium, Zinc, Ghana

\section{Introduction}

Marine products such as fish serves as a vital source of vitamins, protein, minerals like selenium and calcium, and unsaturated essential fatty acids such as omega-3 when consumed by humans $[1,2,3]$. The demand for fish has 
gone up in recent time largely due to its health and nutritional benefits such as the prevention of heart and other diseases [4]. Nevertheless, fish consumption has been identified as one of the pathways by which humans get into contact with environmental pollutants. According to Storelli [3], evidence from research data shows that fish is a major source by which humans are exposed to various environmental contaminants such as metalloids and toxic metals. These compounds exist in the natural environment and finds their way into the aquatic environments through several geochemical means.

Fish in their natural habitat are known to have the capacity to accumulate toxic metals. According to Kasper et al., [6], the fish is a good predictor in assessing environmental contamination, and several research have reported on the use of fish species to evaluate the level of pollution in some potentially affected regions. Although fish and other seafood have nutritional benefits, they also serve as source of health risks due to bioaccumulation of toxins from the aquatic environment which is magnified in food chain [7]. Furthermore, the presence of toxic pollutants in fishes is a manifestation of high metal concentrations in water bodies [8]. The presence of these toxic metals in the aquatic environment has implications for aquatic organisms and the ecosystem as well.

The biodiversity of marine species and the ecosystem are destroyed as a result of indiscriminate discharge of heavy metals into their natural environment due to the high level of toxicity and cumulative behaviour $[9,10]$. The existence of toxic metals in the marine ecosystem may originate from either human activities or natural sources. However, the naturally occurring ones are low in concentration but those from anthropogenic sources such as municipal sewage, industrial and agricultural waste water discharge, geochemical and mining tend to increase their levels in the aquatic ecosystem system [11].

The exposure to toxic metals, results in adverse health effects even at low concentrations, and this entails carcinogenic and neurotoxic actions [12, 13]. The preference for fish as a source of protein has increased among people who have become increasingly conscious about their health as it contains essential omega fatty acids and low saturated fat for good health [14]. However, the bioaccumulation of heavy metals in fish has become a major concern globally due to its associated health risk to humans and the fish [15].

The coast of Western region of Ghana is known for commercial fishing however, over the past few years there has been an increase in other anthropogenic activities including location of automobile repaired shops close to the shore, dumping of solid waste, oil drilling in deep sea among others. These activities result in the release of pollutants such as toxic metals into the surrounding which finds their way into the aquatic ecosystem. Fish in the aquatic ecosystem are thus exposed to these pollutant with the tenancy of bio-accumulating these toxins. There is however little information on the concentration of toxic metals in commercial fish in the region. This study sought to investigate heavy metal concentrations $(\mathrm{Hg}, \mathrm{As}, \mathrm{Cu}, \mathrm{Pb}$, $\mathrm{Cd}, \mathrm{Se}$ and $\mathrm{Zn}$ ) and human health risk of marine fish from the Western region of Ghana.

\section{Materials and Methods}

\subsection{The Study Area}

This research was done in the enclave of the Jubilee Oil Field which is located in the Western part of Ghana (Figure 1). A total of six districts (Jomoro, Ellembelle, Shama, Nzema East, Ahanta West, and Sekondi-Takoradi) were selected with one community from each district. The communities included, Half Assini, Atuabo, Shama, Lower Axim, Dixcove and New Takoradi. The region has a total land area of $23,921 \mathrm{~km}^{2}$ and lies between $5^{\circ} 23^{\prime} 24.71281 \mathrm{~N}$ and $2^{\circ} 8^{\prime} 42.0864 \mathrm{~W}$. The region has a total population of $2,376,031$ representing $9.6 \%$ of the national population [16]. The region has high forest ecological zone with moderate temperature of $22{ }^{\circ} \mathrm{C}$ during the night and $34{ }^{\circ} \mathrm{C}$ during the day. The region has bimodal rainfall with annual rainfall of $1600 \mathrm{~mm}$.

\subsection{Sampling}

\subsubsection{Fish Sampling and Preservation}

Two samples of different species of fish from the sea were collected from fisherman in October, 2014 and March, 2015. A total of 35 and 36 fish species were collected in October, 2015 and March, 2015 respectively. The species collected in October, 2014 and March, 2015 were Caranx crysos, Seriola dumurili, Ethmalosa dorsalis, Sphyreana sphyreana, Selene dorsalis, Brahydeuterus auritus, Sphyraena sphyraena, Sardinella aurieta, Sardinella eba, Hemiramphus brasiliensis, Dentex angolensis, Dentex cogoensis, Chloroscombrus chrysurus, Stromateus fiotola, Pseudotolothus typus, Trichiurus lepturus, Thunnus albacares, Katsuwonus pelamis, Thunnus alalunga, Illisha Africana, Pseudupe prayensis, Lutjanus fulgens, Katsuwonus pelamis, Galeoides decadactyius, Pentanemus quinquarius and Pseudotholitus senegalensis, Mugil cephalus, Pomadasys jubelini, Ethmalosa dorsalis, Trachinotus teraia, Selar crumenophthalmus, Euthynnus alletterattus, Orcynopsis unicolor, Coryhaena equiselis, Orcynopsis unicolor, and Ilisha Africana $(\mathrm{n}=71)$. Foreign materials were removed from the fish using fresh water immediately after collection. 


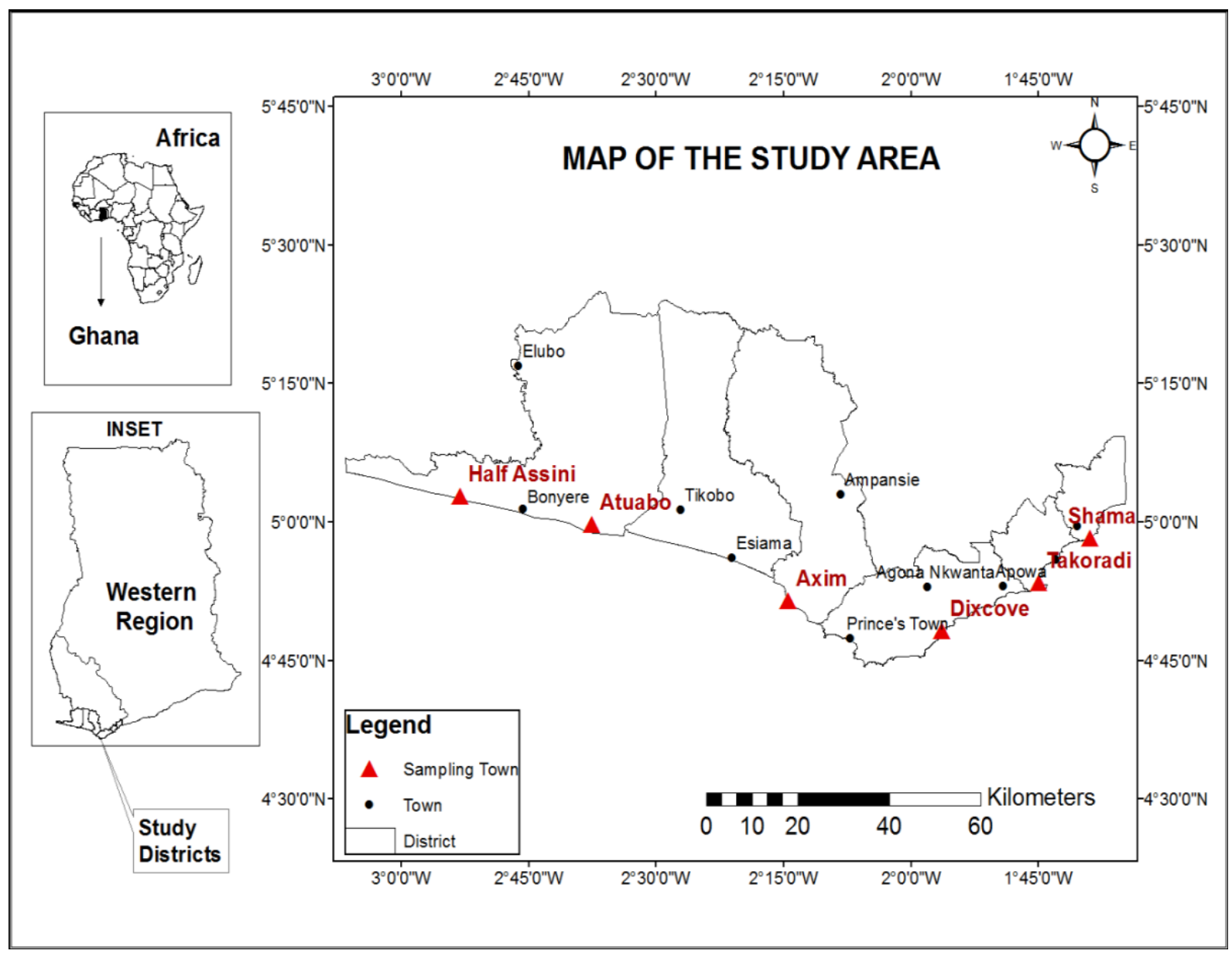

Figure 1. Map of the southwestern coast of Ghana

The samples were placed in a well labelled zip polyethylene bag. The fish samples were preserved in an ice chest packed with ice blocks and sent to the laboratory after 48 hours of collection. Samples were frozen in the refrigerator at $-30{ }^{\circ} \mathrm{C}$ for 72 hours after which laboratory analysis and heavy metals determination were done. Prior to acid digestion, the muscle tissue of the samples were cut using clean stainless steel knife.

\subsubsection{Digestion}

Digestion of fish samples were carried out using the procedure and method by [17]. For heavy metal determination, approximately $0.5 \mathrm{~g}$ of wet weight of fish sample was placed in a digestion tube and $4.0 \mathrm{~mL}$ of $\mathrm{H}_{2} \mathrm{SO}_{4}$ and $3.0 \mathrm{~mL}$ of $\mathrm{HNO}_{3}$ was added to react. The content was then heated on a block digester apparatus at $95{ }^{\circ} \mathrm{C}$. Few drops of hydrogen peroxide $\left(\mathrm{H}_{2} \mathrm{O}_{2}\right)$ was added till the solution was clear. After digestion, the solutions were allowed to cool after which Whatman No 1 filter paper was used to filter the solution into a $100 \mathrm{~mL}$ volumetric flask. The concentration of $\mathrm{Cd}, \mathrm{Cu}, \mathrm{Zn}, \mathrm{Se}$, and $\mathrm{Pb}$ were determined using flame atomic absorption spectrophotometer (FASS). As and Hg were determined using flow injection analysis system (FIAS-ASS) hydride generation technique and cold vapour technique respectively. Air-acetylene flame was used for $\mathrm{Cd}, \mathrm{Cu}, \mathrm{Zn}$, $\mathrm{Se}$, and $\mathrm{Pb}$ whereas argon gas was used for $\mathrm{As}$ and $\mathrm{Hg}$.

The atomic absorption spectrophotometer (Perkin Elmer PinAAcle 900t) was calibrated with known concentration of $\mathrm{Cd}, \mathrm{Cu}, \mathrm{Zn}, \mathrm{Se}, \mathrm{Pb}, \mathrm{As}$, and $\mathrm{Hg}$ and injected into the various system for heavy metal determination. Triplicate measurements were performed.

\subsection{Statistical Analysis}

Descriptive statistics (range, standard deviation and mean) were conducted using excel and SPSS version 20 software. The significant variation in heavy metal concentrations was determined using one-way ANOVA. The correlation between heavy metals was analysed using Pearson multiple correlation analysis.

The hazard quotient (HQ), Estimated Daily Intake (EDI), and Target Hazard Quotients (THQ) were determined for the fish.

The EDI is dependent on the food consumption, the metal concentration in the food, and weight of the body. Health risk assessment of heavy metals as a results of eating contaminated fish was based on the following assumptions: amount consumed equal to the amount of contaminants absorbed [18]. Heat from cooking of food 
does not have effect on the pollutant, and the mean adult body weight was $55.8 \mathrm{~kg}$ [19]. The EDI of the toxic metals was calculated by the use of the following equation [20];

$$
\mathrm{EDI}=\frac{C x I R d}{B w}
$$

where $\mathrm{C}$ represents heavy metals concentration in fish $(\mathrm{mg} / \mathrm{kg}$ wet weight), IRd is daily average i rate $(55.8 \mathrm{~g} /$ day for adults, $52.5 \mathrm{~g} /$ day for children) [21], BW is the mean body weight (30 kg for children and $60 \mathrm{~kg}$ for adult). EDI was represented as $\mu \mathrm{g} / \mathrm{kg}$ bw/day.

\section{Non-carcinogenic Risk}

The non-carcinogenic health risks was determined using the target hazard quotient (THQ) as reported by [18] as the fraction of the estimated amount of the pollutant and the reference amount (RfD) using the equation below

$$
T H Q \text { non }- \text { carcinogenic }=\frac{E F \times E D \times I R d \times C}{\text { RfD } \times \mathrm{W} \times \mathrm{ATn}} \times 10^{-3}
$$

where THQ non-carcinogenic is the target hazard quotient for non-carcinogenic risk, ED is the duration of exposure (70 years estimated for adults and 6 years estimated for children) [18], EF is the rate of exposure (365 days/year), IRd is the rate of ingestion $(55.8 \mathrm{~g} /$ day for adults, 52.5 $\mathrm{g}$ /day for children), $\mathrm{C}$ is the concentration of toxic metals in fish (mg/kg wet weight), RfD is the oral reference amount $(\mu \mathrm{g} / \mathrm{kg} /$ day, 4 for $\mathrm{Pb}, 40$ for $\mathrm{Cu}, 1$ for $\mathrm{Cd}, 1500$ for $\mathrm{Cr}, 20$ for Ni, 0.3 for As 300 for $\mathrm{Zn}$,) [22], BW is the mean weight of the body (60 kg for adult and $30 \mathrm{~kg}$ for a child) and ATn is the mean time of exposure to non-carcinogenic effect $(\mathrm{ED} \times 365$ day/year). The THQ is the ratio of how the individual has been exposed to the reference dose (RfD) and shows the risk of non-carcinogenic effects [22].

The total THQ was calculated as the arithmetic sum of the individual metal THQ values [23].

Total THQ $($ TTHQ $)=$ THQ $($ pollutant 1$)+$ THQ $($ pollutant $2)+\ldots \ldots \ldots+$ THQ (pollutant $n$ )

\section{Results and Discussions}

\subsection{Levels of Toxic Metals in Fish}

The mean levels of the seven toxic metals (As, $\mathrm{Cd}, \mathrm{Cu}$, $\mathrm{Hg}, \mathrm{Pb}, \mathrm{Se}$, and $\mathrm{Zn}$ ) in fish samples in the raining and dry seasons are presented in Table 1. Average levels of toxic metals in fish collected during the wet season (October, 2014) ranged from $0.68-1.32 \mathrm{mg} / \mathrm{kg}$ for $\mathrm{Cu}, 4.25-5.04$ $\mathrm{mg} / \mathrm{kg}$ for $\mathrm{Zn}, 3.40-5.50 \mathrm{mg} / \mathrm{kg}$ for $\mathrm{Se}, 0.004=0.03$ $\mathrm{mg} / \mathrm{kg}$ for As, $0.006-0.06$ for $\mathrm{Hg}, 0.05-0.07 \mathrm{mg} / \mathrm{kg}$ for $\mathrm{Pb}, 0.007-0.012 \mathrm{mg} / \mathrm{kg}$ for $\mathrm{Cd}$ respectively (Table 1 ). The results revealed that the average level of toxic metals analysed in the wet season increased in the order of $\mathrm{Cd}<\mathrm{As}<\mathrm{Hg}<\mathrm{Pb}<\mathrm{Cu}<\mathrm{Zn}<\mathrm{Se}$.

The highest concentration of $\mathrm{Cu}, \mathrm{Pb}, \mathrm{As}$ and $\mathrm{Zn}$ during the wet season was recorded at Half Assini. The highest level of Se was obtained in Shama during the raining season. The analysis of variance (ANOVA) showed that the mean concentration of $\mathrm{Cd}$ and $\mathrm{Cu}$ in fish samples were significantly different $(\mathrm{p}<0.05)$ while $\mathrm{As}, \mathrm{Hg}, \mathrm{Pb}, \mathrm{Se}$, and $\mathrm{Zn}$ were not significant.

\begin{tabular}{|c|c|c|c|c|c|c|c|}
\hline $\begin{array}{l}\text { Element } \\
(\mathrm{mg} / \mathrm{kg})\end{array}$ & Atuabo & Half Assini & Axim & Dixcove & Shama & Takoradi & Mean \pm SD \\
\hline \multicolumn{8}{|c|}{ Wet season } \\
\hline $\mathrm{Cu}$ & $1.25 \pm 0.35^{\mathrm{a}}$ & $1.32 \pm 1.26^{\mathrm{b}}$ & $1.19 \pm 0.36^{\mathrm{a}}$ & $0.68 \pm 0.17^{\mathrm{a}}$ & $0.96 \pm 0.27^{\mathrm{a}}$ & $1.08 \pm 0.26^{\mathrm{a}}$ & $1.08 \pm 0.23$ \\
\hline $\mathrm{Zn}$ & $4.68 \pm 1.29^{\mathrm{a}}$ & $5.64 \pm 0.14^{\mathrm{a}}$ & $4.76 \pm 1.13^{\mathrm{a}}$ & $4.38 \pm 0.18^{\mathrm{a}}$ & $5.01 \pm 0.94^{\mathrm{a}}$ & $4.25 \pm 0.42^{\mathrm{a}}$ & $4.79 \pm 0.50$ \\
\hline $\mathrm{Se}$ & $4.90 \pm 1.00^{\mathrm{a}}$ & $5.20 \pm 1.50^{\mathrm{a}}$ & $5.40 \pm 1.60^{\mathrm{a}}$ & $4.40 \pm 1.20^{\mathrm{a}}$ & $5.50 \pm 1.40^{\mathrm{a}}$ & $3.40 \pm 1.00^{\mathrm{a}}$ & $4.80 \pm 0.80$ \\
\hline $\mathrm{Pb}$ & $0.06 \pm 0.01^{\mathrm{a}}$ & $0.07 \pm 0.01^{\mathrm{a}}$ & $0.07 \pm 0.02^{\mathrm{a}}$ & $0.06 \pm 0.01^{\mathrm{a}}$ & $0.07 \pm 0.02^{\mathrm{a}}$ & $0.05 \pm 0.001^{\mathrm{a}}$ & $0.06 \pm 0.01$ \\
\hline $\mathrm{Hg}$ & $0.06 \pm 0.04^{\mathrm{a}}$ & $0.01 \pm 0.003^{\mathrm{a}}$ & $0.03 \pm 0.04^{\mathrm{a}}$ & $0.04 \pm 0.02^{\mathrm{a}}$ & $0.04 \pm 0.01^{\mathrm{a}}$ & $0.006 \pm 0.004^{\mathrm{a}}$ & $0.031 \pm 0.02$ \\
\hline As & $0.03 \pm 0.01^{\mathrm{a}}$ & $0.03 \pm 0.02^{\mathrm{a}}$ & $0.02 \pm 0.01^{\mathrm{a}}$ & $0.01 \pm 0.003^{\mathrm{a}}$ & $0.004 \pm 0.002^{\mathrm{a}}$ & $0.02 \pm 0.01^{\mathrm{a}}$ & $0.019 \pm 0.01$ \\
\hline $\mathrm{Cd}$ & $0.01 \pm 0.003^{\mathrm{a}}$ & $0.01 \pm 0.003^{\mathrm{a}}$ & $0.01 \pm 0.005 \mathrm{a}$ & $0.01 \pm 0.003^{\mathrm{a}}$ & $0.012 \pm 0.003^{\mathrm{a}}$ & $0.007 \pm 0.001^{\mathrm{b}}$ & $0.01 \pm 0.002$ \\
\hline \multicolumn{8}{|c|}{ Dry Season } \\
\hline $\mathrm{Cu}$ & $3.42 \pm 1.40^{\mathrm{a}}$ & $3.17 \pm 1.75^{\mathrm{a}}$ & $0.48 \pm 0.03^{\mathrm{b}}$ & $0.17 \pm 0.08^{\mathrm{c}}$ & $1.25 \pm 0.4^{\mathrm{d}}$ & $4.50 \pm 0.71^{\mathrm{e}}$ & $2.17 \pm 1.78$ \\
\hline $\mathrm{Zn}$ & $3.35 \pm 2.31^{\mathrm{a}}$ & $2.13 \pm 1.48^{b}$ & $3.86 \pm 0.96^{\mathrm{a}}$ & $1.21 \pm 0.11^{\mathrm{b}}$ & $11.94 \pm 3.29^{\mathrm{c}}$ & $4.83 \pm 1.96^{\mathrm{d}}$ & $4.55 \pm 3.84$ \\
\hline $\mathrm{Se}$ & $6.38 \pm 2.32^{\mathrm{a}}$ & $5.08 \pm 4.95^{\mathrm{a}}$ & $6.41 \pm 3.15^{\mathrm{a}}$ & $6.37 \pm 1.35^{\mathrm{a}}$ & $2.06 \pm 0.26^{\mathrm{b}}$ & $3.94 \pm 2.41^{b}$ & $8.13 \pm 6.19$ \\
\hline $\mathrm{Pb}$ & $0.06 \pm 0.02^{\mathrm{a}}$ & $0.07 \pm 0.03^{\mathrm{a}}$ & $0.06 \pm 0.02^{\mathrm{a}}$ & $0.05 \pm 0.03^{\mathrm{a}}$ & $0.07 \pm 0.01^{\mathrm{a}}$ & $0.05 \pm 0.01^{\mathrm{a}}$ & $0.06 \pm 0.01$ \\
\hline $\mathrm{Hg}$ & $0.04 \pm 0.02^{\mathrm{a}}$ & $0.03 \pm 0.02^{\mathrm{a}}$ & $0.03 \pm 0.01^{\mathrm{a}}$ & $0.02 \pm 0.01^{\mathrm{a}}$ & $0.02 \pm 0.01^{\mathrm{a}}$ & $0.02 \pm 0.01^{\mathrm{a}}$ & $0.03 \pm 0.01$ \\
\hline As & $0.13 \pm 0.04^{\mathrm{a}}$ & $0.03 \pm 0.10^{\mathrm{a}}$ & $0.25 \pm 0.14^{\mathrm{a}}$ & $0.02 \pm 0.004^{\mathrm{a}}$ & $0.05 \pm 0.03^{\mathrm{a}}$ & $0.05 \pm 0.03^{\mathrm{a}}$ & $0.09 \pm 0.08$ \\
\hline $\mathrm{Cd}$ & $0.005 \pm 0.001^{\mathrm{a}}$ & $0.006 \pm 0.002^{\mathrm{a}}$ & $0.004 \pm 0.001^{\mathrm{a}}$ & $0.005 \pm 0.002^{\mathrm{a}}$ & $0.003 \pm 0.001^{\mathrm{a}}$ & $0.005 \pm 0.001^{\mathrm{a}}$ & $0.005 \pm 0.001$ \\
\hline
\end{tabular}

Table 1. Heavy metals concentration in fish samples during the wet and dry season

The superscript alphabets on the on row means significant different at $p<0.05$ 
On the other hand, the mean concentration of fish sampled in the dry season (March, 2015) ranged from 0.17 $-4.50 \mathrm{mg} / \mathrm{kg}$ for $\mathrm{Cu}, 1.21-11.94 \mathrm{mg} / \mathrm{kg}$ for $\mathrm{Zn}, 2.06-$ $6.38 \mathrm{mg} / \mathrm{kg}$ for Se, $0.05-0.07 \mathrm{mg} / \mathrm{kg}$ for $\mathrm{Pb}, 0.02-0.04$ $\mathrm{mg} / \mathrm{kg}$ for $\mathrm{Hg}, 0.02-0.25 \mathrm{mg} / \mathrm{kg}$ for As, and $(.003-0.006$ $\mathrm{mg} / \mathrm{kg}$ for Cd respectively (Table 1 ). The results showed that the average levels of toxic metals analysed in the dry season increased in the order of $\mathrm{Cd}<\mathrm{Hg}<\mathrm{Pb}<\mathrm{As}<\mathrm{Cu}<\mathrm{Zn}<\mathrm{Se}$.

The highest mean of $\mathrm{Pb}$ and $\mathrm{Cd}$ was recorded at Half Assini whereas $\mathrm{Hg}$ and As were obtained at Atuabo and Axim respectively. Additionally, the highest concentration of $\mathrm{Cu}, \mathrm{Zn}$, and Se was recorded at Takoradi, Shama, and Atuabo respectively. Analysis of variance (ANOVA) revealed significant difference $(p<0.05)$ in the concentration of $\mathrm{Cu}, \mathrm{Zn}$, and $\mathrm{As}$ while $\mathrm{Se}, \mathrm{Pb}, \mathrm{Hg}$, and $\mathrm{Cd}$ showed no significant difference $(p>0.05)$ (Table 1).

Excessive amount of heavy metals in food can cause serious health problems in humans. Renieri et al., [24] and WHO, [25] reported effects such as kidney failure and heart related diseases as the cause of high accumulation of $\mathrm{Pb}$.

The permissible limit of toxic metals in food items such as fish and other seafood has been regulated by the EU, WHO, and FAO [26].

Arsenic is a naturally occurring element that is toxic to humans, animals including fish and other seafood and its toxicity differs with different chemical forms [27]. The mean Arsenic concentration in this study ranged from 0.01 $\mathrm{mg} / \mathrm{kg}$ to $0.25 \mathrm{mg} / \mathrm{kg}$. The maximum permissible limit of As is $2.0 \mathrm{mg} / \mathrm{kg}$ wet weight based on Australia New Zealand Food Standards Code, [28]. The concentration of As detected in fish samples were within the ANZFA range. The average levels of As in this research were below the results reported by [29] which ranged from 1.97 to 5.64 $\mathrm{mg} / \mathrm{kg}$ and 2.25 to $6.24 \mathrm{mg} / \mathrm{kg}$ in the post and pre-monsoon seasons respectively. Similarly, the results in this research is in line with the finding of [30] who reported a value of $0-0.04 \mathrm{mg} / \mathrm{kg}$ in Clariasa nguillaris and Oreochromis noliticus from Ghana. The exposure to high concentration of Arsenic is reported to cause skin lesions such as pigmentation, melanosis and kerrtosis [31]. Similarly, Arsenic toxicity is reported to affects the nervous system resulting in difficulties in concentration and learning [32]. Argos et al., [33] reported that the exposure to high level of Arsenic results in respiratory complications while [34] reported correlation of Arsenic exposure and deaths resulting from lungs dysfunctions. Furthermore, long term exposure to Arsenic is reported to results in cardiovascular diseases with risk factors such as hypertension and diabetes.

Lead is a non-essential element which is reported to cause nephrotoxicity, neurotoxicity, and many other health problems [35]. Lead concentrations were detected in fish samples collected in the wet (October 2014) and dry season (March 2015) respectively. The EU maximum permissible limit (MPL) of $\mathrm{Pb}$ in fish flesh is $0.3 \mathrm{mg} / \mathrm{kg}$ [36]. According to Australian National Health and Medical Research Council (ANHMRC) the maximum permissible concentration of $\mathrm{Pb}$ is $2.0 \mathrm{mg} / \mathrm{kg}$. The mean concentration of $\mathrm{Pb}(0.01-0.07 \mathrm{mg} / \mathrm{kg})$ recorded in this study were below the FAO limit of $0.5 \mathrm{mg} / \mathrm{kg}$ reported by [37]. Similarly, the concentration of $\mathrm{Pb}$ in fish samples analysed (Table 1) were lower than the MPL set by the ANHMRC. Furthermore, the level of $\mathrm{Pb}$ in the fish samples were lower than $6.82 \mathrm{mg} / \mathrm{kg}$ reported by [38], $0.085 \mathrm{mg} / \mathrm{kg}$ reported by [39] and $0.08 \mathrm{mg} / \mathrm{kg}$ reported by [30]. The permissible $\mathrm{Pb}$ concentration according to UK Lead in Food Regulations, should not be more than $2 \mathrm{mg} / \mathrm{kg}$ on fresh weight basis [40].

The mean values of $\mathrm{Cd}$ recorded in this study ranged from $0.003 \pm 0.001$ to $0.012 \pm 0.003 \mathrm{mg} / \mathrm{kg}$ (Table 1) which were below than $0.02 \mathrm{mg} / \mathrm{kg}$ [36] and ANHMRC standard of $2.0 \mathrm{mg} / \mathrm{kg}$ for $\mathrm{Cd}$ in seafood. Similarly, the average values of Cd recorded were lower than $0.28 \mathrm{mg} / \mathrm{kg}$ reported by [36]. The presence of cadmium in human is reported to cause persistence toxicity even at low concentration. Exposure to low concentration of $\mathrm{Cd}$ may destroy the cardiovascular system, liver, kidney, sight and hearing ability [41]. In addition, exposure to $\mathrm{Cd}$ even at low concentration is reported to damage human reproductive organs, affect pregnancy, and cause genetic mutation [42].

Copper concentration in the sampled fish ranged from $0.17 \pm 0.08$ to $4.50 \pm 0.71$ The MPL of copper by FAO and ANHMRC is $30 \mathrm{mg} / \mathrm{kg}$. The average values of copper recorded were below the $\mathrm{WHO} / \mathrm{FAO}$ [43] and ANHMRC limit of $30 \mathrm{mg} / \mathrm{kg}$. Copper is important for the synthesis of haemoglobin and also known to be an essential component of many enzymes $[44,45]$, however high intake results in adverse health challenges [46]. Olivares et al. [47] reported effects such as abdominal pain and nausea in human as a result of acute toxicity of copper.

The average concentration of $\mathrm{Hg}$ recorded in the study ranged from $0.006 \pm 0.004$ to $0.07 \pm 0.02 \mathrm{mg} / \mathrm{kg}$ (Table 1). The mean concentration of $\mathrm{Hg}$ detected in this study were lower than those reported by [48] ranging from $0.018-0.1715 \mathrm{mg} / \mathrm{kg}$. Similarly, the mean values of $\mathrm{Hg}$ detected were below the limit of $0.5 \mathrm{mg} / \mathrm{kg}$ set by Japanese regulatory body [4]. Mercury is reported to be one of the most toxic heavy metals in the environment [49]. The brain, kidney and developing fetus can be permanently damage when exposed to high concentration of organic, metallic or inorganic mercury [50].

Selenium mean concentration in the study ranged from 2.06 to $8.13 \mathrm{mg} / \mathrm{kg}$. The concentration of Se in this study is in line with the finding of [51] who reported values of 0.15 $\mu \mathrm{g} \mathrm{g}^{-1}$ to $0.58 \mu \mathrm{g} \mathrm{g}^{-1}$ from the Mediterranean area. However, the concentration of Se in this study is higher than the findings of [52] who reported concentration of $0.27 \mathrm{mg} / \mathrm{kg}$ to $0.56 \mathrm{mg} / \mathrm{kg}$ in Gadus morhus and Sebastes spp respectively. Selenium is vital for human and animal nutrition which is known to be a cellular antioxidant, and a 
protective agent against, cancer and cardiovascular diseases [4]. However, exposure to high concentration of $\mathrm{Se}$ is reported to cause high grade prostate cancer, type two diabetes and Parkinson diseases in human [53-55].

The presence of $\mathrm{Zn}$ was detected in the fish samples collected (Table 1). The average concentration of zinc detected in this study was less than those recorded by [28]. According to [56] the maximum permitted level of $\mathrm{Zn}$ in food such as fish is $150 \mathrm{mg} / \mathrm{kg}$. Zinc is an essential element in human food which undertakes many biochemical functions in human metabolism. Zinc is reported to serve multipurpose function and an essential element for human wellbeing and good health. Zinc is essential in cell-mediated immune functions and serve as an anti-inflammatory agent. Similarly, $\mathrm{Zn}$ has therapeutic benefits such as autoimmune diseases, diabetes, atherosclerosis, cancer, and neurodegenerative disorders, among others [57]. However, exposure to high concentration of $\mathrm{Zn}$ may results in lethargy, vomiting, fatigue, nausea and epigastric pain [58]. Zinc is easily accumulated in fatty tissues of organisms that live in water, including fish.

\subsection{Correlation between Heavy Metals}

Table 2 presents summary results of Pearson correlation analysis for both seasons. This was done to see the interrelationship of the heavy metals and to know if these pollutants comescome from the same source [59]. Significant positive correlations were recorded among $\mathrm{As} / \mathrm{Cu}, \mathrm{Cd} / \mathrm{Se}$, and $\mathrm{Cd} / \mathrm{Pb}$ at 0.05 level of significance (2-tailed), and $\mathrm{Pb} / \mathrm{Se}$ at 0.01 level of significance (2-tailed) respectively during the wet season. Strong positive correlations were also recorded among Se/Zn $(\mathrm{r}=0.701)$, and $\mathrm{Pb} / \mathrm{Zn}(\mathrm{r}=0.779)$ during the wet season. On the other hand, significant positive correlations were found among $\mathrm{Se} / \mathrm{Zn}\left(\mathrm{r}=0.906^{*}\right)$ while strong negative correlation were recorded among $\mathrm{Cd} / \mathrm{Zn}\left(\mathrm{r}=-0.833^{*}\right)$ and $\mathrm{Cd} / \mathrm{Se}\left(\mathrm{r}=-0.822^{*}\right)$ at 0.05 level of significance (2-tailed) respectively during the dry season. The high correlations between specific heavy metals means that this pollutants in the fish might be coming from the same source, dependent on each other and behave similar at the time of their accumulation in the fish [60-62]. The high positive correlation observed could be attributed to the geochemical processes as well as industrial activities in the study area. Thus the increase in one heavy metal, results in the increase of the other. This result is in line with the findings of [60] who reported high correlation between $\mathrm{Fe}$ and $(\mathrm{Cr}, \mathrm{Cu}, \mathrm{As}, \mathrm{Pb}, \mathrm{Zn})$ in sediment. On the other hand, the strong negative correlation observed in some heavy metals $(\mathrm{Cd} / \mathrm{Zn}$ and $\mathrm{Cd} / \mathrm{Se})$ means that the increase in heavy metal results in the decrease of the other, hence these heavy metals are from different sources.

Table 2. Pearson coefficient of correlation of heavy metal in fish samples analysed

\begin{tabular}{|c|c|c|c|c|c|c|c|}
\hline Wet season & $\mathrm{Cu}$ & $\mathrm{Zn}$ & $\mathrm{Se}$ & $\mathrm{Pb}$ & $\mathrm{Hg}$ & As & $\mathrm{Cd}$ \\
\hline $\mathrm{Cu}$ & 1.000 & & & & & & \\
\hline $\mathrm{Zn}$ & 0.549 & 1.000 & & & & & \\
\hline $\mathrm{Se}$ & 0.275 & 0.701 & 1.000 & & & & \\
\hline $\mathrm{Pb}$ & 0.241 & 0.779 & $0.958^{* *}$ & 1.000 & & & \\
\hline $\mathrm{Hg}$ & -0.206 & -0.182 & 0.392 & 0.144 & 1.000 & & \\
\hline As & $0.818^{*}$ & 0.304 & -0.053 & -0.093 & -0.144 & 1.000 & \\
\hline $\mathrm{Cd}$ & -0.128 & 0.515 & $0.882^{*}$ & $0.815^{*}$ & 0.571 & -0.393 & 1.000 \\
\hline Dry season & $\mathrm{Cu}$ & $\mathrm{Zn}$ & $\mathrm{Se}$ & $\mathrm{Pb}$ & $\mathrm{Hg}$ & As & $\mathrm{Cd}$ \\
\hline $\mathrm{Cu}$ & 1.000 & & & & & & \\
\hline $\mathrm{Zn}$ & -0.065 & 1.000 & & & & & \\
\hline $\mathrm{Se}$ & -0.366 & $0.906^{*}$ & 1.000 & & & & \\
\hline $\mathrm{Pb}$ & -0.032 & 0.468 & 0.555 & 1.000 & & & \\
\hline $\mathrm{Hg}$ & 0.253 & -0.353 & -0.327 & 0.274 & 1.000 & & \\
\hline As & -0.252 & -0.051 & -0.136 & 0.025 & 0.518 & 1.000 & \\
\hline $\mathrm{Cd}$ & 0.494 & $-0.833^{*}$ & $-0.822 *$ & -0.217 & 0.316 & -0.315 & 1.000 \\
\hline
\end{tabular}

${ }^{*}$ Significant at $0.05 ;{ }^{* *}$ significant at 0.01 


\subsection{Assessment of Health Risk}

Table 3 presents the calculated estimated daily intake (EDI) values of the toxic metal concentrations. The calculated EDI values for adults ranged from $0.00-4.39$ $\mathrm{mg} / \mathrm{kg}$ bw/day while that of children ranged from $0.008-$ $8.38 \mathrm{mg} / \mathrm{kg}$ bw/day. The results revealed that all the EDI values were below their respective TDI values. The THQ non-carcinogenic of both an adult and a child were significantly less than the hazard quotient threshold of 1 (Table 4). This finding is in line with the findings of [39] who reported the carcinogenic risk of $\mathrm{Pb}$ in fish species to be below $10^{-6}$. Similarly, the results conform to the finding of [30] who reported that non-carcinogenic health risk to humans form the consumption of fish from Ankobra river as values for Hazard Quotient (HQ) were $<1$. The exposed population is thus not likely to sustain health risk because the THQ is less than $1(1<)$. In addition, the total THQ values were also less than 1 which is indicative that there is no possible adverse health risk when the population is exposed through consumption of the fish. The results of Target Hazard Quotient (THQ) in this study are however contrary to that of [30] who reported that the THQ values for adult and children exposed to high concentration of Mercury and Cadmium were $>1$ implying probable health risk to human when consumed. Renieri et al., [24] reported that the intake of high dose of $\mathrm{Pb}$, results in kidney dysfunction, hearted related diseases and central nervous system challenges.

Table 3. The estimated daily intake (EDI) of heavy metals

\begin{tabular}{|c|c|c|c|c|c|c|c|}
\hline \multirow[b]{2}{*}{ Element } & \multicolumn{3}{|c|}{ EDI (adult) } & \multicolumn{3}{|c|}{ EDI (child) } & \multirow[b]{2}{*}{ TDI } \\
\hline & $\min$ & $\max$ & mean & $\min$ & $\max$ & mean & \\
\hline \multicolumn{8}{|c|}{ Wet season } \\
\hline $\mathrm{Cu}$ & 0.62 & 1.21 & 0.99 & 1.19 & 2.31 & 1.89 & 500 \\
\hline $\mathrm{Zn}$ & 3.90 & 5.17 & 4.39 & 7.44 & 9.87 & 8.38 & 300 \\
\hline $\mathrm{Pb}$ & 0.046 & 0.064 & 0.058 & 0.09 & 0.12 & 0.11 & 1.5 \\
\hline $\mathrm{Hg}$ & 0.006 & 0.055 & 0.028 & 0.01 & 0.07 & 0.05 & 0.16 \\
\hline As & 0.004 & 0.028 & 0.017 & 0.007 & 0.055 & 0.03 & 2.14 \\
\hline $\mathrm{Cd}$ & 0.006 & 0.011 & 0.009 & 0.017 & 0.021 & 0.017 & 0.8 \\
\hline \multicolumn{8}{|c|}{ Dry season } \\
\hline $\mathrm{Cu}$ & 0.45 & 4.19 & 2.01 & 0.30 & 7.88 & 3.79 & 500 \\
\hline $\mathrm{Zn}$ & 1.98 & 11.10 & 4.23 & 2.12 & 20.90 & 7.97 & 300 \\
\hline $\mathrm{Pb}$ & 0.04 & 0.07 & 0.06 & 0.09 & 0.12 & 0.11 & 1.5 \\
\hline $\mathrm{Hg}$ & 0.019 & 0.037 & 0.02 & 0.04 & 0.07 & 0.05 & 0.16 \\
\hline As & 0.019 & 0.233 & 0.08 & 0.04 & 0.44 & 0.15 & 2.14 \\
\hline $\mathrm{Cd}$ & 0.003 & 0.006 & 0.004 & 0.008 & 0.011 & 0.008 & 0.8 \\
\hline
\end{tabular}

Table 4. The estimated Target Hazard Quotients (THQ non-carcinogenic) and Total Target Hazard Quotient (TTHQ) of heavy metals

\begin{tabular}{|c|c|c|c|c|}
\hline \multirow[b]{2}{*}{ Element } & \multicolumn{4}{|c|}{ THQ } \\
\hline & $\begin{array}{c}\text { THQ } \\
\text { (adult) }\end{array}$ & $\begin{array}{c}\text { THQ } \\
\text { (child) }\end{array}$ & $\begin{array}{l}\text { TTHQ } \\
\text { (adult) }\end{array}$ & $\begin{array}{l}\text { TTHQ } \\
\text { (child) }\end{array}$ \\
\hline \multicolumn{5}{|c|}{ Wet season } \\
\hline $\mathrm{Cu}$ & 0.025 & 0.047 & 0.303 & 0.262 \\
\hline $\mathrm{Zn}$ & 0.015 & 0.209 & & \\
\hline $\mathrm{Pb}$ & 0.015 & 0.003 & & \\
\hline $\mathrm{Hg}$ & 0.180 & 0.001 & & \\
\hline As & 0.059 & 0.0008 & & \\
\hline $\mathrm{Cd}$ & 0.009 & 0.0004 & & \\
\hline \multicolumn{5}{|c|}{ Dry season } \\
\hline $\mathrm{Cu}$ & 0.05 & 0.10 & 0.38 & 0.302 \\
\hline $\mathrm{Zn}$ & 0.11 & 0.199 & & \\
\hline $\mathrm{Pb}$ & 0.014 & 0.003 & & \\
\hline $\mathrm{Hg}$ & 0.0006 & 0.001 & & \\
\hline As & 0.002 & 0.004 & & \\
\hline $\mathrm{Cd}$ & 0.0001 & 0.0002 & & \\
\hline
\end{tabular}




\section{Conclusions}

The awareness of threshold concentration of toxic metals in fishes is vital. The levels of seven toxic metals (As, $\mathrm{Cd}, \mathrm{Cu}, \mathrm{Hg}, \mathrm{Pb}, \mathrm{Se}$, and $\mathrm{Zn}$ ) were analysed in the muscle of fish samples. Results showed that heavy metal concentration in the muscle of fish varied in the different sampling areas. There was variation in concentration of the various heavy metals analysed. Results of health risk assessment revealed that TTHQ was below $1 \quad(<1)$ indicating no health risk as a result of intake of fish from the enclave of the Jubilee Oil Field.

\section{Data Availability}

Data will be provided when a request is made.

\section{Funding}

This research was supported by University of Ghana (URF/7/LMG-005/20132014).

\section{Conflicting Interests}

There is no competing interest.

\section{Contribution of Authors}

OA, FMBY, AOR., OM, OAE, AD and NFKE, wrote the protocol, designed the study, and data collection. OA, $\mathrm{TI}$ and $\mathrm{AD}$ analysed the data, drafting of the manuscript was done by AO and FMBY. All authors have contributed and edited the manuscript. They also approved the final manuscript. The corresponding author is FMBY.

\section{Acknowledgements}

The authors thank Mr. Emmanuel Ansah and Mr. Prince Owusu for their support analyzing the fish samples. They extend their sincere gratitude to the Department of Clinical, NMIMR and Ecological Laboratory, University of Ghana. Thanks to the District Chief Executives, Chief of Atuabo, Directors and Administrators of Ellembelle, Ahanta West, Nzema East, Jomoro, Secondi-Takoradi, and Shama for their support during the field work.

\section{REFERENCES}

[1] Guérin RC., Vastel C., Sirot V., Volatier J., Leblanc J., L. Noël, "Determination of 20 trace elements in fish and other seafood from the French market Thierry", Food Chemistry,
127,934-942, 2011. DOI: 10.1016/j.foodchem.2011.01.061

[2] Pieniak Z., Wim V., S. Joachim, "Health related beliefs and consumer knowledge as determinants of fish consumption," Journal of Human Nutrition and Detetics, 23(5), 480-488, 2010. DOI: 10.1111/j.1365-277X.2010.01045.X

[3] Storelli MM., "Potential human health risks from metals $(\mathrm{Hg}, \mathrm{Cd}$, and $\mathrm{Pb})$ and polychlorinated biphenyls (PCBs) via seafood consumptionEstimation of target hazard quotients (THQs) and toxic equivalents (TEQs)," 46, 2782-2788. 2008. DOI: $10.1016 /$ j.fct.2008.05.011

[4] Medeiros RR., dos Santos IM., Freire AS., Santelli RE., Braga AMCB., Krauss TM., SDC. Jacob, "Determination of inorganic trace elements in edible marine fish from Rio de Janeiro State," Brazil. Food Control, 23, 535-541, 2012. DOI: 10.1016/j.foodcont.2011.08.027

[5] Morgano MA., Rabonato LC., Milani RF., Miyagusku L., SC Balian, Assessment of trace elements in fishes of Japanese foods marketed in Sao Paulo (Brazil). Food Control, 22, 778-785. 2011. DOI: 10.1016/j.foodcont.201 0.11 .016

[6] Kasper D., Botaro D., Palermo EFA., \& O. Malm, "Mercúrio em peixes e fontes e contaminação" Oecologia Brasiliensis, 11(2), 228-239, 2007. DOI: 10.4257/oeco.20 07.1102 .07

[7] Türkmen M., Türkmen A., Tepe Y., Töre Y., A. Ates, "Determination of metals in fish species from Aegean and Mediterranean Seas," Food Chemistry, 113, 233-237, 2009. DOI: $10.1016 /$ j.foodchem.2008.06.071

[8] Pintaeva ET., Bazarsadueva SV., Radnaeva LD., Pertov EA., OG. Smirnova, "Content and character of metal accumulation in fish of the Kichera River (a tributary of Lake of Baikal),". Contemporary Problems of Ecology, 4, 64-68, 2011. DOI: 10.1134/S1995425511010103

[9] Ebrahimpour M., Pourkhabbaz A., Baramaki R., Babaei H., M. Rezaei, "Bioaccumulation of heavy metals in freshwater fish species Anzali, Iran" Bulletin of Environmental Contamination and Toxicology, 87(386-392), 2011. DOI: 10.1007/s00128-011-0376-y

[10] Uluturhan E., F. Kucuksezgin, "Heavy metal contaminants in Red Pandora (Pagellus erythrinus) tissues from the Eastern Aegean Sea, Turkey," Water Research, 41, 11851192, 2007. DOI: 10.1016/j.watres.2006.11.044

[11] Mendil D., Demirci Z., Tuzen M., M. Soylak, "Seasonal investigation of trace element contents in commercially valuable fish species from the Black sea, Turkey," Food and Chemical Toxicology, 48, 865-870, 2010. DOI: 10.1016/j.fct.2009.12.023

[12] Agency for Toxic Substance and Disease Registry, "Toxicological Profile for Selenium, U.S. Department of Health and Humans Services, Public Health Service, Centres for Diseases Control, Atlanta, GA," 2003. https:/www.atsdr.cdc.gov/ToxProfiles/tp92.pdf

[13] Agency for Toxic Substance and Disease Registry, "Toxicological Profile for Lead, U.S. Department of Health and Humans Services, Public Health Service, Centres for Diseases Control, Atlanta, GA," 2007.

[14] Copat C., Bella F., Castaing M., Fallico R., Sciacca S., M. Ferrante, "Heavy metals concentrations in fish from Sicily 
(Mediterranean Sea) and evaluation of possible health risks to consumers," Bulletin of Environmental Contamination and Toxicology, 88, 78-83, 2012. DOI: 10.1007/s00128-011-0433-6

[15] Lee K., Kweon H., Yeo J., Woo S., Han S., J. Kim, "Characterization of tyrosine-rich Antheraea pernyi silk fibroin hydrolysate," International Journal of Biological Macromolecules, 48, 223-226, 2011. DOI: 10.1016/j.ijbiomac.2010.09.020

[16] Ghana Statistical Service. "Population and housing census: Summary report of final results. Accra, Ghana," 2010.

[17] Hanson NW., "Official Standardized and Recommended Methods of Analysis (2nd ed.). London," The Society for Analytical Chemistry, 270-274, 1973. DOI: $10.1039 /$ SA973100185A

[18] USEPA, Risk assessment guidance for superfund. In: Human Health Evaluation Manual Part A, Interim Final, vol. I. United States Environmental Protection Agency, Washington (DC). EPA/540/1-89/002. 1989. https://www.epa.gov/sites/default/files/2015-09/documents /rags_a.pdf

[19] Cooper CB., Doyle ME., K., Kipp, "Risk of consumption of contaminated seafood, the Quincy Bay Case Study". Environmental Health Perspectives 90, 133-140. 1991. DOI: 10.1289/ehp. $90-1519503$

[20] Griboff J., Wunderlin DA., MV. Monferran, Metals, As and Se determination by inductively coupled plasma-mass spectrometry (ICP-MS) in edible fish collected from three eutrophic reservoirs". Their consumption represents a risk for human health? Microchem. J. 130, 236-244. 2016. DOI: 10.1016/j.microc.2016. 09.013.

[21] Ahmed ASS., Sultana S., Habib A., Ullah H., Musa N., Hossain MB., Rahman MM., MSI. Sarke, Bioaccumulation of heavy metals in some commercially important fishes from a tropical river estuary suggests higher potential health risk in children than adults. PLoS ONE 14. 1-21. 2019. DOI: 10.1371/journal.pone.0219336

[22] Varol M., Kaya KG., A. Alp, Heavy metal and arsenic concentrations in rainbow trout (Oncorhynchus mykiss) farmed in a dam reservoir on the Firat (Euphrates) River: risk-based consumption advisories. The Science of the Total Environment 599-600, 1288-1296. 2017. DOI: 10.1016/j.scitotenv.2017.05.052

[23] Chien LC., Hung TC., Choang KY., Yeh CY., Meng PJ., Shieh MJ., BC. Han, Daily intake of TBT, $\mathrm{Cu}, \mathrm{Zn}, \mathrm{Cd}$ and As for fishermen in Taiwan. The Science of the Total Environment 285, 177-185. 2002. DOI: 10.1016/S0048-9697(01)00916-0

[24] Renieri EA., Safenkova IV., Alegakis AK. Slutskaya ES., Kokaraki V., Kentouri M., Dzantiev BB., AM. Tsatsakis, 'Cadmium, lead and mercury in muscle tissue of gilthead seabream and seabass: risk evaluation for consumers', Food Chemistry. Toxicology. 124, 439-449. 2019. DOI: 10.1016/S0048-9697(01)00916-0

[25] WHO Global Health Observatory. 2020.https://www.who.int/countries/gha/en/

[26] Xue ZJ., Liu SQ., YL. Liu, "Health risk assessment of heavy metals for edible parts of vegetables grown in sewage-irrigated soils in suburbs of Baoding City, China," Environment Monitoring Assessment, 184, 3503-3513, 2012. DOI: $10.1007 / \mathrm{s} 10661-011-2204-6$

[27] Devesa V., Vélez D. R. Montoro, "Effect of thermal treatments on arsenic species contents in food," Food and Chemical Toxicology, 46, 1-8, 2008. DOI: 10.1016/j.fct.2007.08.021

[28] ANZFA, “Australian and New Zealand Food Standards Code, Standard 1.4.1- Contaminants and Natural Toxicants (F2011C00542)," 2011.

[29] Rahman, MS., Molla AH., Saha N., A. Rahman, "Study on heavy metals levels and its risk assessment in some edible fishes from Bangshi River,Savar,Dhaka Bangladesh". Food Chemistry, 134(4), 1847-1854, 2012. DOI: 10.1016/j.foodchem.2012.03.099

[30] Kortei, N. K., Heymann, M. E., Essuman, E. K., Kpodo, F. M., Akonor, P. T., Lokpo, S. Y., Boadi, N. O., Ayim-Akonor M., C. Tettey,. Health risk assessment and levels of toxic metals in fishes (Oreochromisnoliticus and Clariasanguillaris) from Ankobrah and Pra basins: Impact of illegal mining activities on food safety. Toxicology Reports 7: 360-369, 2020. DOI: 10.1016/j.toxrep.2020.02. 011

[31] Rahman, MM., Ng, JC., R. Naidu, Chronic exposure to arsenic via drinking water and its adverse health impacts on humans, Environmental Geochemistry and Health 31,1, 189-200., 2009. DOI: 10.1007/s10653-008-9235-0

[32] Mundey MK., Roy, M., Awasthi, MK R. Sharma, Antioxidant potential of Ocimum sanctum in arsenic induced nervous tissue damage. Braz. Journal of Vetinary Pathology 2013, 6, 95-101.

[33] Argos, M., Kalra, T., Rathouz, PJ., Chen, Y., Pierce, B., Parvez, F., Islam, T., Ahmed, A., Rakibuz-Zaman, M., Hasan, R., Sarwar, G., Slavkovich, V., van Green, A., Graziano, J., H. Ahsan, Arsenic exposure from drinking water, and all-cause and chronic-disease mortalities in Bangladesh (HEALS), 2010, a prospective cohort study. Lancet 376, 252-258. DOI: 10.1016/S0140-6736(10)60481 $-3$

[34] Parvez, F., Chen, Y. Yunus, M., Zaman, R-U., Ahmed, A., Islam, T., Argos, M., Hasan, R., Slavkovich V, V., J. Graziano, Associations of arsenic exposure with impaired lung function and mortality from diseases of the respiratory system; findings from the health effects of Arsenic Longitudinal Study (HEALS). Epidemiology 22, S179, 2011, DOI: 10.1097/01.ede.0000392225.89379.73

[35] Arcia-Leston J., Mendez J., Pasaro E., B. Laffon, "Genotoxic effects of lead: an updated review". Environmental International, 36, 623-636, 2010. DOI: 10.1016/j.envint.2010.04.011

[36] European Union, "Setting maximum levels for certain contaminants in foodstuffs, Commission Regulation (EC)" No 1881/2006; OJ L 364, 20.12.2006, 5-8, 2006.

[37] FAO, "Compilation of legal limits for hazardous substances in fish and fishery products," Food and Agriculture Organization, FAO Fish Circ., 464:5-100, 1983. http://www.fao.org/docrep/014/q5114e/q5114e.pdf

[38] Akoto O., Eshun, BE., Darko G., E. Adei, "Concentrations 
and Health Risk Assessments of Heavy Metals in Fish from the Fosu Lagoon," International Journal of Environmental Resource 8, 403-410, 2014. DOI: 10.22059/IJER.2014.731

[39] Kwaansa-Ansah EE., Nti SO., F. Opoku, Heavy metals concentration and human health risk assessment in seven commercial fish species from Asafo Market, Ghana. Food Science Biotechnology, 28(2):569-579, 2019. DOI: 10.1007/s10068-018-0485-Z

[40] Cronin MI., Davies M., Newton A., Pirie JM., Topping G. S. Swan, "Trace metal concentrations in deep sea fish from the North Atlantic," Marine Environmental Research, 45, 225238, 1998. DOI: 10.1016/S0141-1136(98)00024-5

[41] Genchi, G., Sinicropi, MS., Lauria, G. Carocci, A., A. Catalano, The Effects of Cadmium Toxicity. International Journal of Environmental Res. Public Health 17, 3782; 2020, DOI: 10.3390/ijerph17113782.

[42] Kumar, S.; Sharma, A. Cadmium toxicity: Effects on human reproduction and fertility. Reviews on Environmental Health2019, 34, 327-338. DOI: 10.1515/reveh-2019-0016

[43] WHO/FAO Codex Alimentarius Commission, Second Series,". CAC/FAL, Rome 3: 1-8. Food and drugs. KualaLumpur, Malaysia Law Publisher, 1984.

[44] Maughan RJ. "Role of micronutrients in sport and physical activity," British Medical Bulletin, 55(3), 683-690, 1999.

[45] Sivaperumal P., Sankar TV. PGV. Nair, "Heavy metal concentrations in fish, shellfish and fish products from internal markets of India vis-a-vis international standards," Food Chemistry, 102, 612-620, 2007. DOI: 10.1016/j.foodchem.2006.05.041

[46] Krishna, AK., PK. Govil, "Heavy metal contamination of soil around Pali industrial area, Rajasthan, India," Environmental Geology, 47(1), 38-44, 2004. DOI: 10.1007/s00254-004-1124-y

[47] Olivares, Mm, Araya, M., Pizarro, F., R. Uauy, Nausea threshold in apparently healthy individuals who drink fluids containing graded concentrations of copper. Regulatory Toxicology and Pharmacology, 33, 271-275. 2001. DOI: $10.1006 / \mathrm{rtph} .2000 .1440$

[48] Vieira CS., Morais S., Ramos C., Delerue-matos, M., BPP. Oliveira, "Mercury, cadmium, lead and arsenic levels in three pelagic fish species from the Atlantic Ocean: Intraand inter-specific variability and human health risks for consumption". Food and Chemical Toxicology 49, 923-932, 2011. DOI: 10.1016/j.fct.2010.12.016

[49] Castro-González MI. M. Méndez-Armenta, "Heavy metals: Implications associated to fish consumption," Environmental Toxicology and Pharmacology, 26, 2008. DOI: 10.1016/j.etap.2008.06.001

[50] Agency for Toxic Substance and Disease Registry, "Toxicological Profile for Mercury, U.S. Department of Health and Humans Services, Public Health Service, Centres for Diseases Control, Atlanta, GA," 1999.

[51] Barone G., Storelli, A., Meleleo D., Dambrosio A., Garofalo, R., Busco, A., MM. Storelli, Levels of Mercury,
Methylmercury and Selenium in fish: Insights into children food safety. Toxics 2021, 9, 39. DOI: 10.3390/ toxics9020039.

[52] Azad, AM., Frantzen, S., Bank, MS., Nilsen, BM., Duinker, A., Madsen, L., A. Maage, Effect of geography and species variation on selenium and mercury molar ratios in Northeast Atlantic marine fish communities. Science of the Total Environment. 652, 2019, 1482-1496. DOI: 10.1016/j.scitot env.2018.10.405

[53] Vinceti, M., Filippini, T., LA. Wise, Environmental Selenium and Human Health: an Update. Curr Envir Health Rpt 5, 464-485 (2018). DOI: 10.1007/s40572-018-0213-0

[54] Kenfield, SA., Van Blarigan, EL., DuPre, N., Stampfer, MJ., Giovannucci, E., JM., Chan, Selenium supplementation and prostate cancer mortality. J. Natl. Cancer Inst. 107, 1, 360. 1-8, 2014. DOI: 10.1093/jnci/dju360.

[55] Kristal AR., Darke AK., Morris JS., Tangen CT., Goodman PJ., Thompson IM., Meyskens Jr. FL., Gary EG., Minasian LM., Parnes HL., Lippman, SM., EA. Klein, Baseline selenium status and effects of selenium and Vitamin E supplementation on prostate cancer risk. J. Natl. Cancer Inst. 106, 3, 1-8, 2014. DOI: 10.1093/jnci/djt456.

[56] FAO/WHO List of maximum levels recommended for contaminants by the Joint FAO/WHO Codex Alimentarius Commission [1976] FAO, Rome (Italy). Food Policy and Nutrition Div.; World Health Organization, Geneva, Switzerland.

[57] Chasapis, CT., Panagoula-Stamatina, AN., Spiliopoulou, CA, Stefanidou, ME. Recent aspects of the effects of zinc on human health. Archives of Toxicology, 1-19, 2020. Doi: 10.1007/s00204-020-02702-9

[58] Fosmire, GJ. Zinc toxicity. The American Journal of Clinical Nutrition, 1990, 51, 2, 225-227 DOI: 10.1093/ajen/51.2.225.

[59] Effendi, H., Kawaroe, M., Mursalin, D., F. Lestari. Ecological Risk Assessment of Heavy Metal Pollution in Surface Sediment of Mahakam Delta, East Kalimantan, Procedia Environmental Sciences. 33, 574-582, 2016. DOI: 10.1016/j.proenv.2016.03.110

[60] Risandi, DP., Tri, A., Ani, S, Henky, I., Tengku, SR, Try, Y., Wiwin, KA., JK.,Chandra, Preliminary study of heavymetal $(\mathrm{Zn}, \mathrm{Pb}, \mathrm{Cr}, \mathrm{As}, \mathrm{Cu}, \mathrm{Cd}$ ) contaminations on different soil level from post-mining bauxite production for aquaculture. E3S Web of Conferences 47, 02008, 2018. DOI: $10.1051 / \mathrm{e} 3$ sconf/20184702008.

[61] Al-Mur, BAA. Quicksall, N., AMA. Al-Ansari, Spatial and temporal distribution of heavy metals in coastal core sediments from the Red Sea, Saudi Arabia. Oceanologia, 59, 262-270. 2017. DOI: 10.1016/j.oceano.2017.03.003

[62] Ali, MM., Ali, ML., Islam, MS., MZ., Rahman. Environmental Nanotechnology, Monitoring \& Management, 5, 27-35 (2016). DOI: 10.1016/j.enmm.2016 .01 .002 